\title{
ESTATE TAXATION OF CONTRACT RIGHTS SUBJECT TO CONDITIONS PRECEDENT*
}

THE federal estate tax reaches property attributable to a decedent which is transferred at death, created by death or conveyed inter vivos in a manner approximating testamentary disposition. ${ }^{1}$ Considered expectancies rather than property, contract rights subject to conditions precedent ${ }^{2}$ do not fall within those sections of the Code which include transferred property in the gross estate. ${ }^{3}$ If, however, the conditions defining an expectancy do not survive the

*Goodman v. Granger, 243 F.2d 264 (3d Cir.), cert. denied, 78 Sup. Ct. 57 (1957).

1. INT. Rev. Cone of 1954, §\$ 2033-43.

Since they are levied upon the occurrence of a particular event, death duties are indirect taxes, constitutional without apportionment among the states. See New York Trust Co. v. Eisner, 256 U.S. 345 (1921) (estate tax); Knowlton v. Moore, 178 U.S. 41 (1900) (inheritance tax) ; Scholey v, Rew, 90 U.S. (23 Wall.) 331 (1874) (succession tax). The constitutionality of an estate tax upon inter vivos transfers has also been upheld. See Milliken v. United States, 283 U.S. 15 (1931) (transfers in contemplation of death) ; Helvering v. Bullard, 303 U.S. 297 (1938) (transfers with retained life estate); Commissioner v. Erickson, 74 F.2d 327 (1st Cir. 1934), cert. denied, 294 U.S. 730 (1935) (transfers taking effect at death) ; Helvering v. City Bank Farmers r rust Co., 296 U.S. 85 (1935) (revocable transfers). But see Heiner v. Donnan, 285 J.S. 312 (1932) (conclusive presumption that transfers made less than two years prior ) death are in contemplation of death unconstitutional). Generally, taxation of inter ivos conveyances is considered necessary to prevent avoidance of the testamentary ansfer tax. Bittker, Federal Income Estate and Gift Taxation 900 (1955); Paul, Federal Estate and Gift Taxation 40 (1942). For a detailed discussion of ' 1e purposes behind estate taxation of inter vivos transfers, see Knouff, Death Taxes on Comleted Transfers Inter Vivos, $36 \mathrm{MrcH}$. L. Rev. 1284 (1938).

2. Most expectancy cases refer to conditions which prevent vesting, see, e.g., Estate of M. Hadden Howell, 15 T.C. 224,228 (1950), but use of "precedent" and "subsequent" to designate conditions which do or do not prevent vesting provides a more accurate terminology.

3. Dimack v. Corwin, 19 F. Supp. 56 (E.D.N.Y. 1937), aff'd on other gronnds, 99 F.2d 799 (2d Cir. 1938), aff'd, 306 U.S. 363 (1939); Molter v. United States, 146 F. Supp. 497 (E.D.N.Y. 1956); Hanner v. Glenn, 111 F. Supp. 52 (W.D. Ky. 1953), aff'd por curian, 212 F.2d 483 (6th Cir. 1954); Estate of Albert L. Salt, 17 T.C. 92 (1951); Estate of M. Hadden Howell, supra note 2; Estate of William S. Miller, 14 T.C. 657 (1950) ; Estate of Emil A. Stake, 11 T.C. 817 (1948) ; Illinois Merchants Trust Co., 12 B.T.A. 818 (1928) ; Estate of Frank M. Gordon, 9 CCH Tax Ct. Mem. 424 (1950). But see Estate of Frederick J. Twogood, 15 T.C. 989, 993 (1950), aff'd, 194 F.2d 627 (2d Cir. 1952) ; Estate of Albert B. King, 20 T.C. 930 (1953).

Expectancies most frequently confront the courts as aspects of deferred compensation and death benefit plans. See Freyburger, Employec Benefit Plans-Taxability of Death Bencfits, 23 TAXEs 962 (1945) ; Nelson, The New \$5,000 Death Benefit, 31 Taxes 629, 632-34 (1953); Note, Federal Estate and Gift Tax Aspects of Employee Benefit Plans, 48 Col.uMr. L. Rev. 393, 395-97 (1948). An employee's interests may be forfeitable upon discretionary termination of the plan by the employer, Dimock v. Corwin, supra, failure to reach a certain age or to serve the employer for a specified number of years, Estate of Emil A. Stake, supra, working for a competing firm, committing a felony or executing 
decedent, the interest may be embraced by other sections-governing dower rights, life insurance policies and annuity contracts-which include property created at death. ${ }^{4}$ But such interests often lie beyond the compass of the creation

a voluntary assignment, Estate of William S. Miller, supra. Conditions of forfeitability may terminate at death, Molter v. United States, supra, or remain operative beyond it, Estate of Albert L. Salt, supra.

Contingent remainders may be distinguished from expectancies as nonvested interests nevertheless considered as property. See Estate of Charlotte D. M. Cardeza, 5 T.C. 202 (1945), aff'd, 173 F.2d 19 (3d Cir. 1949). However, commentators differ on the meaning of Cardeza. Compare Lowndes \& Kramer, Federal Estate and Gift Taxes 35 (1956) (hereinafter cited as Lowndes \& Kramer); Warren \& SURrey, Feneral Estate and Gift Taxation 105 (1956), with 1 Beveridge, Law of Federal Estate Taxatron $\S 2.08$, at $59-60$ (1956).

Presently, the estate tax definition of an expectancy differs markedly from the general meaning of the term. See 1 Simes \& SMith, The Law of Future Interests $\S 391$ (2d ed. 1956); 1 AMrerican LAw of Property $\$ 4.1$, at n.2 (Casner ed. 1952); RestateMrent, Property § 315 (1940). But see Thorp v. Randazzo, 41 Cal. 2d 770, 264 P.2d 38 (1953) ; Grimm v. Grimm, 26 Cal. 2d 173, 157 P.2d 841 (1945). Although the Treasury Department would eliminate this dissimilarity, G.C.M. 27242, 1952-1 CuM. BurL. 160 (reversing the position taken in G.C.M. 17817, 1937-1 CuM. BuLL. 281), the courts have retained it. Molter v. United States, supra; Hanner v. Glenn, supra. See Lowndes \& KRAMER 51-52.

Certain sections of the Code apply exclusively to property transferred or subject to transfer by the decedent. INT. REv. CODE of 1954, §§ 2033 (property transferred at death, see note 14 infra), 2035 (property transferred in contemplation of death), 2036 (transfers with retained life estate), 2037 (transfers taking effect at death), 2038 (revocable transfers), 2040 (property passing from decedent to joint tenant under right of survivorship; interest attributable to joint tenant but acquired from decedent for less than full consideration included to extent consideration insufficient), 2041 (property transferred or subject to transfer by a general power of appointment), 2043 (transfers for insufficient consideration).

4. See INT. Rev. CoDE of 1954, $\$ \S 2034,2039,2042$. Section 2034 includes in decedent's gross estate dower or curtesy interests of a surviving spouse. In states retaining commonlaw or statutory inchoate dower, a wife holds an expectancy in a certain portion of her husband's property. See 1 AMrerican LAw of PROPERTY $\$ 5.31$ (Casner ed. 1952); 3 Vernier, AMrerican Family Laws 355-71 (1935). A husband's interest in his wife's property under statutes enacted to supplant curtesy rights is also an expectancy. 1 Adrerican Law of Property $\$ 5.65$ (Casner ed. 1952); 3 Vernier, Adierican Fanily LAws 538-52 (1935). In these jurisdictions, one spouse's death transforms the other's expectancy into property. By including the value of these interests in the decedent's gross estate, $\S 2034$ applies to property created at death. Where no inchoate right is recognized, $\$ 2034$ operates as a transfer section, since all property is unencumbered while both husband and wife are alive and dower or curtesy simply require a transfer of property rights from one spouse to the other.

Under $\$ 2039$, if decedent had an expectancy in an annuity or other payment and received at least one installment before death, the value to his estate or survivor of the subsequent payments is included in the gross estate as property created at death. Set notes 27-33 infra and accompanying text. Section 2042 includes in the gross estate property receivable as insurance by the executor or, providing decedent retained certain incidents of ownership, by other beneficiaries. Thus, proceeds receivable by the executor would be included although forfeitability of the policy prevented decedent's possession 
sections." In this event, the distinction between property and expectancies permits valuable rights of the decedent to be transferred at death without estate tax incidence. ${ }^{0}$ The possibilities of tax avoidance are great since qualifications sufficient to make a right an expectancy have been found in conditions within the control of the decedent ${ }^{\tau}$ or dependent upon the unlikely action of the promisor. 8

In the recent case of Goodman $v$. Granger, however, contract rights subject to voiding conditions which terminated at death did not escape taxation even though the creation sections were not applicable. ${ }^{9}$ Decedent had contracted for deferred compensation payments to begin when his employment ceased. ${ }^{10}$ If he died before the due date of any installments, the remaining payments were to be made to his estate or as he should direct by will.11 Both

of a property interest before death. In a forfeitable policy payable to a beneficiary other than the executor, the requisite ownership may be lacking.

Voiding conditions attached to interests includible under the dower and life insurance sections necessarily lapse at death and the interests are included in the gross estate at full value. In annuities under $\$ 2039$, the conditions may survive the decedent and thereby affect the includible value. See note $40 \mathrm{infra}$. In such cases, $\S 2039$ imposes a tax on the transfer of expectancies.

For recognition that the estate tax may be levied on the creation of property at death, see Fernandez v. Wiener, 326 U.S. 340, 352 (1945) ; Tyler v. United States, 281 U.S. 497, 502 (1930); cf. Bromley v. McCaughn, 280 U.S. 124, 136 (1929), negating the idea, expressed in several cases, see YMCA v. 'Davis, 264 U.S. 47, 50 (1924); Edwards v. Slocum, 264 U.S. 61, $62-63$ (1924) ; Nichols v. Coolidge, 274 U.S. 531, 537 (1927), that the estate tax is only imposed on the decedent's interests "ceasing" at death.

5. See Comment, Estate Taxation of Employee Death Benefits, 66 YAlE L.J. 1217, 1230-33 (1957); Garner, Income and Estate Taxation of Amnities, N.Y.U. 13TH INST. ON FED. TAX. 265, 289 (1955).

6. These interests may not pass entirely tax-free since they can be taxed to the recipient as income in respect of a decedent. See INT. Rev. Cone of 1954, § 691(a). If an estate tax is also paid on the interests transferred by the decedent, the recipient may deduct his share of the total estate tax from his gross income. Id. $\$ 691(\mathrm{c})$. Since the taxpayer receives a deduction rather than a credit against his income tax, see U.S. Treas. Reg. $\$ 1.691$ (c) (1957), estate tax avoidance still affords substantial advantages. See, generally, Irell, Inconc in Respect of Decedents as Affected by the 1954 Internal Revenue Code, 1955 U. So. CALIF. TAx Inst. 535; Drye, The Taxation of a Decedent's Income, S TAX L. REv. 201. (1953).

7. See Estate of William S. Miller, 14 T.C. 657 (1950) (employment with competitor, voluntary assignment and commission of a felony).

8. The promisor may be unlikely to invoke a condition either because of business practice, see Lowndes \& Kramer 51-52; Comment, Estate Taxation of Employee Death Bicnefits, 66 Y ALE L.J. 1217, 1248 (1957); Note, 6 Stan. L. Rev. 473, 479 (1954) (business reality minimizes chance that employer will invoke reserved right to terminate benefits), or because of a tacit understanding with the promisee, see Estate of Albert L. Salt, 17 T.C. 92, 97, 100 (1951) (benefits under pension plan payable at employer's discretion held expectancy even though no eligible beneficiary had been denied payments during the total fifteen-year life of the plan).

9. 243 F.2d 264 (3d Cir.), cert. denied, 78 Sup. Ct. 57 (1957).

10. Id. at 266 .

11. Id. at $266 \mathrm{n} .2$. 
employment and the thrust of the conditions were terminated by death.12 The lower court's classification of the contracts as valueless expectancies was reversed, ${ }^{13}$ and the present worth of the future installments included in the gross estate under the general testamentary transfer section. ${ }^{14}$

Encompassing transfers of property, this section necessarily contemplated property held by the decedent before death. ${ }^{15}$ Possibly, therefore, the court

12. Id. at 269. The conditions were:

"(1) That the Employee shall have duly performed his services hereunder . . . throughout the period expiring January 31, 1945 [1946, 1947];

"(2) That the Employee shall not have engaged in a competing business . . .

"(i) During the period of two (2) years beginning with the date when the Employee ceased to be employed by the Employer, in any city ... having a population of over two hundred thousand $(200,000)$ without having first procured the written consent of the Employer;

"(ii) During the period of three (3) years beginning with the date when the Employee ceased to be employed by the Employer, in any city in which the Employer ... maintains a retail store, without having first procured the written consent of the Employer.

“....

"5. Contingent payments shall be eliminated or reduced to the extent necessary . . . in order that the business earnings of the Employee, together with the contingent payment herein provided for, shall not in respect of any year exceed $75 \%$ of the yearly average of payments to the Employee . . . in the last three fiscal years preceding the date when he shall have ceased to be employed by the Employer."

Brief for Appellant, app., pp. 11a-13a, Goodman v. Granger, 243 F.2d 264 (3d Cir. 1957).

13. The district court noted in dictum that decedent's contract rights were expectancies and held that, regardless of the nature of the rights, they were valueless as of the moment prior to decedent's death and therefore did not increase the total worth of his gross estate. Goodman v. Granger, 56-1 U.S.T.C. If 11595 (W.D. Pa. 1956). In reversing, the Third Circuit not only decided that the contracts were property includible in decedent's gross estate but held that their value must be determined as of the moment after death. 243 F.2d at $268-69$; see note 21 infra.

14. Int. Rev. Code of 1939, $\S 811$ (a), 53 Stat. 120 (now INT. Rev. Code of 1954, $\$ 2033)$ : "Gross estate-The value of the gross estate of the decedent shall be determined by including the value at the time of his death of all property, real or personal, tangible or intangible, wherever situated, except real property situated outside of the United States-(a) Decedent's interest. To the extent of the interest therein of the decedent at the time of his death; ...." This provision applies only to property possessed by a decedent at the time of his death, which is susceptible of transfer. Lowndes \& KRANEEt 27-28; Warren \& Surrey, Federal Estate and Gift Taxation 93 (1956); $1 \mathrm{CCH}$ FED. Est. \& GrFT TAX REP. If 1300.42. The value of a life estate in property cannot be included in the gross estate since it cannot be transmitted. Hugh T. Rhodes, 41 B.T.A. 62 (1940), aff'd, 117 F.2d 509 (8th Cir. 1941); Williams v. United States, 41 F.2d 895 (Ct. C1. 1930) ; see U.S. Treas. Reg. 80, art. 11 (1934). Similarly, any interest obliterated by death is not included in the gross estate. Commissioner v. Rosser, 64 F.2d 631 (3d Cir. 1933) ; Davis v. United States, 27 F. Supp. 698 (S.D.N.Y. 1939) ; Rev. Rul. 55-438, 1955-2 Cunr. BuLL. 601.

15. The absence of a property interest which could be transferred underlies the decision reached in Dimock v. Corwin, 19 F. Supp. 56 (E.D.N.Y. 1937), aff'd on other 
viewed the qualifications attached to the contracts as conditions subsequent. ${ }^{16}$ If conditions precedent, they would have made the contract rights expectancies rather than property interests; and decedent, not possessing property before death, could not have transferred property at death. Yet characterization of the Goodman limitations-noncompetition, diligent service and limited business income-as conditions subsequent is without support in prior case law. ${ }^{17}$ Such a definition would, moreover, effectively overrule cases holding that conditions capable of causing forfeiture preclude classification of a decedent's interest as property. ${ }^{18}$ Since the court is unlikely to have intended so signifi-

grounds, 99 F.2d 799 (2d Cir. 1938), aff'd, 306 U.S. 363 (1939), the leading case concerning estate taxation of expectancies. Dimock held that an expectancy could not be included in the decedent's gross estate under the general testamentary transfer section even though death transformed the expectancy into a vested property right. Id. at 58 . Implicit in this conclusion is the assumption that a property interest cannot be transferred unless possessed by the transferor. See Lowndes \& KRANIER 27-28; see also note 3 supra. Thus, the Treasury has ruled that property in which decedent had no interest while alive is not encompassed by the testamentary transfer provision. Rev. Rul. 54-19, 1954-1 Cum. BuLl 179 (proceeds receivable by decedent's intestate successors in settlement of wrongful death claim); Rev. Rul. 56-637, 1956-2 CuM. BulL. 600 (payment to decedent's widow under workmen's compensation law). Social security death benefits are included in the gross estate if payable to the estate, E.T. 10, 1937-2 Curr. BurL. 469, but are excluded if paid to beneficiaries designated by statute, E.T. 18, 1940-2 Curr. Burr. 285. The rights to such benefits are established prior to death, and a decedent who designates the ultimate beneficiary transfers a property interest at death. On the other hand, although nonforfeitable property rights are earned by decedent prior to death, such rights are not the property of the decedent if disposition of the benefits occurs independent of his direction.

16. See note 19 infra.

In Estate of Albert B. King, 20 T.C. 930 (1953), the decedent-employee took part in a special company bonus plan. Benefits under the plan were receivable in four annual installments-the first payable immediately, the remainder left to a custodian to invest in company stock. The employee was the owner of the stock bought with money taken from his account with the bonus custodian, but was required to give the custodian the right to receive dividends and to sell. If the employee left the company or was dismissed, any stock credited to his account was forfeited. If he died while still employed, remaining stock in the account was to be paid to his estate. Characterizing the conditions as subsequent, the tax court held that decedent possessed a vested interest in the stock rather than an expectancy. King has been thought to portend elimination of the expectancy concept in estate taxation. See Childs, Deferred Compensation Plans for Executives, 31 TAXES 1007, 1020 (1953). But the bonus stock in King, although forfeitable, was bought in decedent's name, and he alone could exercise stockholder's rights. Such incidents of ownership, lacking in both Goodman and other expectancy cases, provided a foundation for the tax court's conclusion that King possessed a vested property interest. Estate of Albert B. King, supra at 935.

17. See Estate of M. Hadden Howell, 15 T.C. 224 (1950) (condition of continued service prevents vesting); Estate of William S. Miller, 14 T.C. 657 (1950) (condition of noncompetition a voiding condition). But see Estate of Albert B. King, discussed in note 16 stipra. For a listing of contingencies usually appearing in deferred compensation plans, see Childs, supra note 16 , at 1017-18.

18. See cases cited note 3 supra; note 17 supra. 
cant a deviation from case law without discussion, Goodman probably included the contract rights in the gross estate without disturbing the traditional categorization of conditions. ${ }^{19}$

Inclusion of the contract rights apparently stemmed from an approach judging the interests transferred by decedent as of the moment immediately following death. Evoked by death, the estate tax could not have been levied on interests whose nature was determined at any time prior to death. Otherwise, the court reasoned, improper exclusion or inclusion of property acquired or disposed of after the time of determination would be conceptually possible. ${ }^{20}$ But even if the interests possessed by a decedent at death cannot be defined until he is dead, their character may still be ascertained as of the instant before death. And, while prior cases have suggested the moment after death as the proper time to evaluate includible interests, ${ }^{21}$ use of that time to determine includibility under a transfer section is a radical innova-

19. The considerations which impelled the court to its conclusion that decedent possessed an interest in property are unclear. The question is speedily dispatched, 243 F.2d at 268, and no mention is made of the expectancy characterization pronounced by the district court.

20. Ibid.

21. The problem of evaluation appears frequently in pre-1954 Code cases concerning survivorship annuities, contracts producing payments to a decedent while alive and then to a designated beneficiary. In all the cases, the decedent's interest in the annuities was nonforfeitable, and the issue was limited to the value placed upon the property transferred at death. According to the Treasury Department, the value to be added to the gross estate was the cost of a comparable contract at the date of decedent's death. U.S. Treas. Reg. 105, \& 81.10(i) (1942). Yet the nature of the comparable contract, and consequently its value, depends upon whether the decisive moment is the instant before or after death. For death transforms a survivorship contract into a single life annuity and enhances the value of the rights receivable by the survivor, since the secondary right to payment is no longer impaired by the continued life of the primary annuitant. Compare Christiernin v. Manning, 138 F. Supp. 923 (D.N.J. 1956) (comparable contract to be determined as of the moment after death), with Estate of William J. Higgs, 12 T.C. 280 (1949), rev'd on other grounds, 184 F.2d 427 (3d Cir. 1950) (comparable contract is a survivorship annuity rather than a single life policy). See also Mearkle's Estate v. Commissioner, 129 F.2d 386 (3d Cir. 1942); Grant v. Smyth, 123 F. Supp. 771 (N.D. Cal. 1954) ; Estate of Judson C. Welliver, 8 T.C. 165 (1947); cf. In the Matter of the Estate of Endemann, 307 N.Y. 100, 120 N.E.2d 514 (1954) ; 55 Colun. L. REv. 762 (1955). The evaluation problem in regard to survivorship annuities has been dispelled by $\S 2039$ of the 1954 Code. See note 27 infra.

The courts have also disagreed on the value to be placed upon notes made to the decedent by insolvent makers when decedent's death sufficiently enriched the debtors to enable payment of the face amounts of the notes. Again, the value of the notes depends upon the moment, either before or after decedent's death, as of which they are evaluated. Compare Estate of Elizabeth V. Harper, 11 T.C. 717 (1948), with Estate of Edwin Hodge, 2 T.C. 643,647 (1943) (dictum). See also Estate of William Walker, 4 T.C. 390 (1944).

Goodman evaluated decedent's contract rights as of the moment after death. 243 F.2d at 269. A contrary viewpoint would lead to unfair results in cases where the value of property interests was decreased by decedent's death. See Newell v. Commissioner, 66 F.2d 102 (7th Cir. 1933) (value of decedent's interest in a close corporation determined with regard to loss incurred by corporation as a result of decedent's death). 
tion. ${ }^{22}$ Decedent held an expectancy until death terminated the conditions and transformed the contract rights into a property interest. Although a tax on property created at death is constitutionally valid, ${ }^{23}$ when levied under a section intended to reach only transfers, it perverts the structure of the estate $\operatorname{tax}^{24}$

Nevertheless, this approach would resolve certain of the problems created by the expectancy-property dichotomy. Conditions, sham or otherwise, which did not survive the decedent would no longer insulate the transfer of valuable interests at death from estate taxation. The estate would assume a share of the tax burden proportionate to its real value. Since the amount of distributable property would be identical to that available had property been transferred rather than created at death, this share would not be oppressive. ${ }^{25}$ However, Goodman would not include in the gross estate rights subject to conditions which survived the decedent. To the extent such conditions do not seriously depreciate the rights, valuable interests might still be conveyed at death without estate tax liability. More generally, a solution to the expectancy loophole, which, like Goodman, modifies the structure of the estate tax, might better lie with Congress than the courts. ${ }^{26}$

Arising under the 1939 Code, Goodnan did not involve the innovations of section 2039 of the present Code. ${ }^{27}$ Section 2039 includes in a decedent's gross estate payments receivable by a surviving beneficiary which were also "payable to the decedent" or which the decedent "possessed the right to re-

22. See note 15 supra.

23. See notes 1, 4 supra.

24. See notes 14,15 supra.

25. Excluding from the gross estate rights subject to voiding conditions which terminate at decedent's death would, on the other hand, be inequitable. When the conditions expire, the recipient of the rights thereby vested receives exactly the same interest as he would have received had the rights been vested in the decedent and transferred at death.

26. Cf. Catterall, Judicial Self-Restraint: The Obligation of the Judiciary, 42 A.B.A.J. 829 (1956); McWhinney, The Supreme Court and the Dilemma of Judicial Policy-Making, 39 Mrnn. L. REv. 837 (1955) ; Palmer, Causes of Dissents: Judicial Self-Restraint or Abdication?, 34 A.B.A.J. 761 (1948).

27. INT. REv. CODE of 1954, \& 2039. The pertinent provisions of this section are: "(a) .... The gross estate shall include the value of an annuity or other payment receivable by any beneficiary by reason of surviving the decedent under any form of contract or agreement... (other than as insurance under policies on the life of the decedent), if, under such contract or agreement, an annuity or other payment was payable to the decedent, or the decedent possessed the right to receive such annuity or payment, either alone or in conjunction with another for his life or for any period not ascertainable without reference to his death or for any period which does not in fact end before his death. (b) .... Subsection (a) shall apply to only such part of the value of the annuity or other payment receivable under such contract or agreement as is proportionate to that part of the purchase price therefor contributed by the decedent. For purposes of this section, any contribution by the decedent's employer ... to the purchase price of such contract or agreement ... shall be considered to be contributed by the decedent if made by reason of his employment." Subsection (c) exempts "qualified" plans from inclusion in the gross estate. See Comment, Estate Taxation of Employee Death Benefits, 66 YalE L.J. 1217, 
ceive."28 The former requirement is satisfied if the decedent received at least one payment during life, ${ }^{29}$ the latter if he possessed a right to present payments or a nonforfeitable right to future payments at the moment before death. ${ }^{30}$ Contracts of the Goodman type may be beyond the reach of section

1219-22 (1957). Section 2039 applies to decedents dying after December 31, 1953. Decedent in Goodman died in May 1947. 243 F.2d at 266.

Prior to the enactment of $\$ 2039$, the Commissioner had difficulty including survivorship annuities in decedent's gross estate. If a decedent had purchased the contract himself, the courts would require inclusion by analogizing the annuity to a transfer with a retained life estate or a transfer taking effect at death. See Mearkle's Estate v. Commissioner, 129 F.2d 386 (3d Cir. 1942) ; Commissioner v. Clise, 122 F.2d 998 (9th Cir. 1941), cert. denied, 315 U.S. 821 (1942) ; Commissioner v. Wilder's Estate, 118 F.2d 281 (5th Cir.), cert. denied, 314 U.S. 634 (1941). See also Murphy, The Surviz'orship Annuity: Estate Tax Kaleidoscope, 1 Howard I.J. 1, 11 (1955); Comment, Estate Taxation of Employee Death Benefits, 66 Yale L.J. 1217, 1222 n.22 (1957). But if decedent received the contract from his employer as deferred compensation, the courts were inclined to exclude the annuity. If decedent's rights under the contract were forfeitable, the annuity was not included since the decedent had no property to transfer. Hanner v. Glenn, 111 F. Supp. 52 (W.D. Ky. 1953) ; Estate of M. Hadden Howell, 15 T.C. 224 (1950). In addition, the survivor's interest was separable from that of the primary annuitant, and no interest in the survivor's benefits was ever held by the decedent. Commissioner v. Twogood's Estate, 194 F.2d 627 (2d Cir. 1952) ; Herrick v. United States, 108 F. Supp. 20 (E.D.N.Y. 1952).

Section 2039 was specifically designed to overcome the transferor problem by including in the gross estate survivorship annuities purchased by employers to the extent that they emanated from the employment relationship. S. REP. No. 1622, S3d Cong., 2d Sess. 123, 471 (1954) ; H.R. Rep. No. 1337, 83d Cong., 2d Sess. 90-91, A314 (1954). Presently, all nonqualified survivor benefits provided for by agreements under which the employeedecedent either receives or has a right to receive payments while he lives will be included in the gross estate. The notion of separability is negated. Since the amount receivable by the beneficiary is determinative, S. REp. No. 1622, 83d Cong., 2d Sess. 470 (1954); H.R. REp. No. 1337, 83d Cong., 2d Sess. A315 (1954), the includible value problem, see note 21 supra, is also resolved by the statute.

The courts have yet to decide whether or not $\$ 2039$ encompasses forfeitable survivorship contracts similar to the agreement in Goodman. Commentators have proposed various answers. See Garner, supra note 5, at 285; Murphy, supra at 36; Pyle, Income, Estate and Gift Taxation of Life, Accident and Sickness Insurance and Amnities under the 1954 Code, 1956 Tulane Tax Inst. 467, 658-59; Note, 6 Stan. L. Rev. 473, 489 (1954) ; Comment, Estate Taxation of Employee Death Benefits, 66 YaLE L.J. 1217, 1223-25 (1957). The Treasury seems to endorse an affirmative position. See Proposed U.S. Treas. Reg. $\S$ 20.2039-1(b), Example (3) (1956); Comment, Estate Taxation of Employee Death Benefits, 66 Y ALE L.J. 1217, 1224 n.30 (1957).

28. INT. Rev. CoDE of 1954, § 2039 (a).

29. Proposed U.S. Treas. Reg. $\$ 20.2039-1$ (b) (2) (1956) ; Comment, Estate Taxation of Employee Death Benefits, 66 Y ALE L.J. 1217, 1224 n.30 (1957) ; Note, 6 Stan. L. Kev. 473, 486 (1954). See S. REp. No. 1622, 83d Cong., 2d Sess. 470, Examples (1)-(3), (5) (1954); H.R. Rep. No. 1337, 83d Cong., 2d Sess. A314-15, Examples (1)-(3), (5) (1954).

30. See S. Rep. No. 1622, 83d Cong., 2d Sess. 470, Examples (1)-(3), (5) (1954); H.R. Rep. No. 1337, 83d Cong., 2d Sess. A314-15, Examples (1)-(3), (5) (1954); Pyle, supra note 27, at 658 ; Garner, supra note 5, at 285; Note, 6 StAN. L. REv. 473, 485 (1954). 
2039 , since decedent's right to future payments was at all times forfeitable hefore his death. ${ }^{31}$ Nevertheless, a proposed treasury regulation would apply section 2039 to a Goodman situation. ${ }^{32}$ The regulation implies that decedent had the requisite "right to receive" if, at the moment before death, a possibility existed that he would, at some future time in life, possess an enforceable claim to payments. ${ }^{33}$ Thus, if decedent at death possessed an expectancy, as in Goodman, a possibility of future vesting would justify inclusion of the contract rights in the gross estate under section 2039. But this interpretation - equating possibility with right-overreaches the statutory language. Furthermore, neither the interpretation nor section 2039 can reach contracts

31. Comment, Estate Taxation of Employce Death Benefits, 66 YaLe L.J. 1217, 1224 n.30 (1957) ; Pyle, supra note 27, at 658. The sole indication that Congress envisioned application of $\$ 2039$ to forfeitable annuities appears in an example in the congressional reports: "A contract or agreement entered into by the decedent and his employer under which at decedent's death, prior to retirement or prior to the expiration of a stated period of time, an annuity or other payment was payable to a designated beneficiary if surviving the decedent." S. Rep. No. 1622, 83d Cong., 2d Sess. 470, Example (4) (1954); H.R. Rep. No. 1337, s3d Cong., 2d Sess. A315, Example (4) (1954). Example (4) has been read to embrace forfeitable annuities which vest in the survivor at death. Note, 6 STAN. L. REv. 473, 487 (1954). But the example is designed to illustrate only one type of annuity which would be included in the gross estate even though no payment was made to decedent. Whether or not the employee's right to receive a payment was forfeitable depends on whether the contract required him to continue his employment until retirement or the "expiration of a stated period of time." Such a condition might have been attached. On the other hand, the employee may have been entitled to receive payments upon premature termination of employment. Annuity contracts are designed to return premiums paid plus interest. Comment, Estate Taxation of Employee Death Benefits, 66 YALE L.J. 1217 (1957). Thus, the employee might have had a right to receive the premiums plus interest which his services had earned, see $i d$. at 1241 , however they ceased. Moreover, since annuity contracts do not shift the risk of premature death, see $i d$. at 1217 , his designated beneficiaries would, if the contract is properly classifiable as an annuity and hence within $\$ 2039$, receive the same amount whether at the moment he died he had just terminated his employment or remained in faithful service. If his beneficiaries would receive a greater amount had the employee not prematurely terminated his employment immediately before death, the contract would have risk-shifting features and the proceeds would be properly classifiable as insurance, includible under $\$ 2042$ not $\$ 2039$. For prior to retirement or the "expiration of a stated period of time," the contract would be functionally insurance; after that date, it would become an annuity. See id. at 1238-42.

In sum, if decedent's beneficiaries will receive more than decedent's services earned upon his premature death, the contract is insurance, and forfeitability is irrelevant. If they will receive only what he earned, and the contract is an annuity, decedent may have an enforceable right to the premiums earned, regardless of the length of his employment, on an unjust enrichment rationale. In any event, the example is at least ambiguous. And reading in forfeitability seems unreasonable in light of the absence of direct, or even other possible indirect, consideration of the problem in the congressional reports.

32. See Proposed U.S. Treas. Reg. $§ 20.2039-1$ (b), Example (3) (1956).

33. Ibid. The Treasury's position was foreshadowed by the suggestion of a so-called "contemplates-an-annuity-in-the-employee test" in Note, 6 STAN. L. REv. 473, 488 (1954). 
providing death benefits unaccompanied by lifetime features. ${ }^{34}$ If such contracts are also contingent until decedent's death, they cannot be included under other sections of the Code unless functionally insurance. ${ }^{35}$

Congressional adoption of the Goodman approach, judging interests as of the moment after death, would eliminate these shortcomings. A statutory scheme which subjects property interests created at death to the general testamentary transfer provision, the net effect of Goodman, would clearly preclude use of contingencies which do not survive the decedent to avoid tax liability on transfers at death. Postdeath determination would also bring within the estate tax some annuity arrangements containing lifetime features which currently avoid section 2039 even as interpreted by the Treasury Department. If an employer reserves absolute discretion to revoke payments at any time prior to decedent's death and does not make any payments to the decedent while alive, benefits receivable by a beneficiary, although mandatory, may not be included in the gross estate by section 2039. To the extent action in reliance does not create an obligation in the promisor, ${ }^{36}$ the decedent never possessed the possibility of acquiring the requisite right to receive payments under the contract. ${ }^{37}$ The Goodman approach would not, however, affect the scope of sections governing inter vivos conveyances since they are predicated upon decedent's possession of property at the time of transfer not death. ${ }^{38}$ Consequently, an inter vivos conveyance of an expectancy would escape taxation even though the limiting conditions could not survive the decedent.

To close the loopholes created by the expectancy classification, cases holding that rights subject to conditions precedent are not property must be judicially or legislatively overruled. With the expectancy category thus

34. See Int. Rev. Code of 1954, \$2039(a) ; Comment, Estate Taxation of Employee Death Benefits, 66 YALE L.J. 1217, 1247-48 (1957).

35. Death benefits in the form of insurance may be included under INT. REv. CODE OF $1954, \S 2042$, although forfeitable before death. See note 4 supra. For a functional analysis of insurance, see Comment, Estate Taxation of Employee Death Benefits, 66 YaLE L.J. $1217,1233-48$ (1957).

36. See 1 CORBIN, CoNTracts $\S 201$ (1950). In some jurisdictions, an employer's promise of future benefits payable or terminable at his discretion is an unenforceable gratuity even though designed to induce continuation of the employment relationship. Hughes v. Encyclopaedia Britannica, Inc., 1 IIl. App. 2d 514, 117 N.E.2d 880 (1954) ; Spooner v. Reserve Life Ins. Co., 47 Wash. 2d 454, 287 P.2d 735 (1955). However, other states recognize the employee's reliance on such promises as consideration binding the employer. Tilbert $v$. Eagle Lock Co., 116 Conn. 357, 165 Atl. 205 (1933) ; Psutka v. Michigan Alkali Co., 274 Mich. 318, 264 N.W. 385 (1936) ; Mabley \& Carew Co. v. Borden, 129 Ohio St. 375, 195 N.E. 697 (1935). See, generally, Comment, 34 MrCH. L. Rev. 700 (1936).

The existence of an enforceable right in the promisee may depend upon whether he was actually and reasonably misled by the promise. See 1 Corbin, Contracts $\$ 201$ (Supp. 1957) ; 49 HaRv. L. REv. 148, 149 (1935). An employer's record of honoring similar promises in the past might be significant in this regard. See Proposed U.S. Treas. Reg. $\$ 20.2039-1$ (b), Example (4) (1956). But see Estate of Albert L. Salt, 17 T.C. 92, 100 (1951).

37. See Proposed U.S. Treas. Reg. § 20.2039-1(b) (2) (1956).

38. INT. Rev. CODE of 1954, §§ 2035-38, 2041. 
eliminated, contract rights becoming property would not give rise to inequitable taxation. Conditions invoked before death and preventing the decedent or his estate from receiving any benefits would, by destroying the rights to which they were precedent, also preclude estate tax liability. ${ }^{39}$ If the conditions survived the decedent, the rights would be included in the gross estate but only to the extent of their fair market value. ${ }^{40}$ More important, all sections formerly pertinent only to transfers of property would apply to conditional contract rights, and valuable interests devolving from a decedent at death would no longer be sheltered from taxation by meaningless property distinctions. ${ }^{41}$

39. Commissioner v. Rosser, 64 F.2d 631 (3d Cir. 1933) ; Davis v. United States, 27 F. Sưpp. 698 (S.D.N.Y. 1939) ; Rev. Rul. 55-438, 1955-2 Cuns. BulL. 601.

40. See Proposed U.S. Treas. Reg. $\S 20.2039-1$ (b), Example (2) (1956). If payments under a survivorship annuity were made to a decedent, or if he possessed the right to receive them, the Treasury would include the survivor's interest in the gross estate under $\S 2039$ even if it were forfeitable upon breach of a condition by the survivor. Ibid. But the evaluation of such an interest would reflect its forfeitable nature. Ibid. See also Childs, supra note 16, at 1020; Note, 6 Stan. L. REv. 473, 479 (1954). Death benefits voluntarily paid by an employer would still not be subject to estate taxation, since neither a forfeitable nor a vested right to property would be transferred. See Estate of John C. Morrow, 19 T.C. 1068 (1953) ; Estate of Jack Messing, 7 CCH Tax Ct. Mem. 568 (1948); United States Trust Co., 9 B.T.A. 514 (1927). But see Estate of Raphael A. Casilear, 4 $\mathrm{CCH}$ Tax Ct. Mem. 970 (1945) (noncontractual, contingent death benefits payable as "gratuity" to decedent's appointee held property included in gross estate).

41. The Supreme Court has sharply denounced the use of outmoded property concepts in estate taxation. See Helvering v. Hallock, 309 U.S. 106, 118 (1940) : "Distinctions which originated under a feudal economy when land dominated social relations are peculiarly irrelevant in the application of tax measures now so largely directed toward intangible wealth." 